\title{
PERAN ORGANIZATIONAL CITIZENSHIP BEHAVIOR TERHADAP SUBJECTIVE WELL-BEING PADA GURU PEREMPUAN
}

\author{
THE ROLE OF ORGANIZATIONAL CITIZENSHIP BEHAVIOR AGAINST \\ SUBJECTIVE WELL-BEING ON WOMEN TEACHERS \\ ${ }^{1}$ Fatwa Tentama, ${ }^{2}$ Nina Zulida Situmorang, ${ }^{3)}$ Willytiyo Kurniawan \\ Program Studi Magister Psikologi, Fakultas Psikologi \\ Universitas Ahmad Dahlan \\ Jalan Kapas No.9, Semaki, Umbulharjo, Semaki, Umbulharjo, Yogyakarta 55166 \\ ${ }^{1}$ fatwa.tentama@psy.uad.ac.id, ${ }^{2}$ nina.situmorang@psy.uad.ac.id, \\ ${ }^{3}$ willytiyo.kurniawan@gmail.com
}

\begin{abstract}
ABSTRAK
Penelitian ini bertujuan untuk mengetahui peran organizational citizenship behavior terhadap subjective well-being. Sampel penelitian ini adalah 150 guru perempuan SMK di Kota Yogyakarta. Teknik pengambilan sampel yang digunakan untuk penelitian ini adalah teknik simple random sampling. Instrumen yang digunakan adalah skala subjective well-being dan skala organizational citizenship behavior. Teknik analisis data yang digunakan adalah analisis product moment dari Pearson. Hasil analisis data menunjukkan koefisien korelasi sebesar 0,346 dengan signifikansi $0,000(\mathrm{p}<0,01)$, artinya bahwa terdapat hubungan yang sangat siginfikan antara organizational citizenship behavior dengan subjective well-being.
\end{abstract}

Kata kunci: guru perempuan, organizational citizenship behavior, subjective well-being 


\begin{abstract}
This study aims to determine the role of organizational citizenship behavior on subjective well-being. The sample of this study was 150 female vocational school teachers in the city of Yogyakarta. The sampling technique used for this research is simple random sampling technique. The instruments used are the subjective well-being scale and organizational citizenship behavior scale. The data analysis technique used is Pearson's product moment analysis. The results of data analysis showed a correlation coefficient of 0.346 with a significance of 0.000 ( $\mathrm{p}<0.01$ ), so that it could be interpreted that there was a very significant relationship between organizational citizenship behavior and subjective wellbeing.
\end{abstract}

Keywords: organizational citizenship behavior, subjective well-being, women teachers 


\section{PENDAHULUAN}

Kebahagiaan menjadi salah satu tujuan hidup setiap individu karena bahagia akan membuat individu nyaman dan kehidupan yang dijalaninya akan terasa lebih berharga dan berkualitas. Kebahagian setiap individu berbedabeda, mereka mempunyai nilai atau standar tersendiri untuk kebahagiaan bagi kehidupannya. Meraih kebahagian bukan hal mudah bagi setiap individu. Perkerjaan, gaji, keluarga, tahta dan religiusitas bagi sebagian individu adalah sebagian dari keinginan individu untuk mencapai kebahagiaan. Para peneliti menggunakan sebutan subjective well-being untuk memaparkan kebahagiaan seseorang. Kebahagiaan merupakan kata yang lebih mudah diakses atau digunakan dalam perspektif popular sebagai pengganti istilah kesejahteraan subjektif (Lopez \& Snyder, 2007).

Mempunyai pekerjaan yang layak sudah menjadi keinginan setiap individu salah satunya adalah pekerjaan yang berkiprah di dunia pendidikan yaitu menjadi seorang guru. Pendidikan tidak akan bisa berjalan optimal jika tidak ada peran guru di dalam proses pembelajaran. Proses pembelajaran merupakan suatu tugas utama guru yaitu memberikan pelajaran kepada para siswa dengan menerapkan pendekatan dengan siswa secara perlahan serta membantu siswa membangun karakter yang baik.
Guru juga merupakan bagian penting dalam tercapainya tujuan pendidikan. Peran guru sangat besar dalam memberikan pembelajaran kepada pelajar untuk mendapatkan pendidikan yang baik dan layak. Sanjaya (2006) mengatakan peran guru dalam proses pembelajaran yaitu: guru sebagai sumber belajar, guru sebagai pengelola, guru sebagai fasilitator, guru sebagai demonstrator, guru sebagai pembimbing, guru sebagai motivator, guru sebagai elevator.

Tanggung jawab seorang guru untuk mendidik siswa bisa dianggap mudah. Tanggung jawab yang dipikul guru sangat berat untuk membuat siswa menjadi seorang yang berprestasi dan memiliki pribadi yang baik. Guru sebagai pendidik yang menjadi contoh baik bagi para siswa, menjadi orangtua kedua bagi para siswa di sekolah. Beratnya tanggung jawab yang dipikul oleh guru terkadang tidak sesuai dengan kesejahteraan yang mereka dapatkan. Belakangan ini banyaknya timbul persoalan tentang kurangnya kesejahteraan guru. Kesejahteraan guru yang kurang dan tidak merata berdampak pada menurunnya kualitas dan semangat guru dalam memberikan ilmu serta membuat guru tidak bahagia dalam memberi ilmu pengetahuan. Hal ini dikarenakan upah yang diterima guru tidak sesuai dengan kinerja dan tanggung jawab yang mereka lakukan. Program sertifikasi guru 
yang dicanangkan dan dilakukan pemerintah bertujuan untuk memenuhi kesejahteraan pada guru, tetapi hanya sedikit guru yang mendapat program tersebut. Banyak guru lainnya yang sudah mengabdi puluhan tahun tetap masih belum mendapatkan program tersebut, serta banyak nya status guru yang bekerja honorer tetapi tanggung jawab dan pekerjaan mereka sama. Pemerintah pada saat ini masih kurang tanggap dalam menangani kesejahteraan guru sehingga membuat guru tidak mendapatkan kebahagiaan yang mereka harapkan.

Pavot dan Diener (2004) mengatakan subjective well-being berdampak pada kualitas sosial, kehidupan kerja, dan kesehatan mental individu dengan subjective well-being yang tinggi mudah dalam mengolah dan mempertahankan persahabatan, hubungan romantis, dan pernikahan. Subjective wellbeing adalah evaluasi individu terhadap kesejahteraan psikologisnya, atau dengan kata lain happiness. Subjective well-being mempunyai dua unsur afektif dan kognitif, yang berarti ketika individu merasa bahagia dan secara kognitif individu menilai hidupnya memuaskan bisa kita kategorikan individu tersebut memiliki subjective well-being yang tinggi. Afektif bisa dikaitkan dengan emosi, suasana hati, dan perasaan. Kognitif mengarah kepada pemikiran individu terhadap kepuasan hidup secara menyeluruh dan spesifik (Nayana, 2013).

Hasil penelitian Thomas dan Diener (Diener, Oshi, \& Lucas, 2005) bahwa kebahagiaan dipengaruhi oleh suasana hati, keyakinannya kebahagiaan, dan seberapa mudahnya seseorang menerima informasi positif dan negatif. Kebahagiaan juga berkaitan dengan seberapa mampu individu menilai pengalaman hidupnya secara positif. Tingkat kebahagiaan akan berubah seiring berjalannya perjalanan hidup seseorang, terutama karena kejadian-kejadian hidup yang dapat meningkatkan kebahagiaan (pernikahan, kelahiran anak, kesuksesan). Namun kebahagiaan juga dapat menurun karena adanya peristiwa yang menyedihkan (kematian kerabat, perceraian, dan kegagalan) sehingga tingkat kebahagiaan tidak akan menetap. Perubahan tingkat kebahagiaan seseorang disebabkan oleh kemampuan adaptasi individu terhadap situasi di lingkungannya (Astuti dan Anganthi, 2016). Penelitian yang dilakukan (Fahrunnisak \& Qudsyi, 2015) tentang perbedaan subjective wellbeing antara guru bersertifikasi dan non sertifikasi. Penelitian ini bertujuan untuk perbedaan subjective well-being antara guru bersertifikasi dan non sertifikasi. Hasil penelitian menunjukkan tidak ada perbedaan subjective well being antara guru yang bersertifikasi mengajar dan 
guru yang tidak bersertifikasi mengajar. Begitu pula, tidak ada perbedaan subjective well being jika ditinjau dari aspek, yaitu komponen afektif (afek positif dan afek negatif) dan komponen kognitif (kepuasan hidup) serta ditinjau dari faktor demografis subjek, seperti jenis kelamin, pendapatan.

Pada saat ini tuntutan seorang guru sangat tinggi, guru diharapkan dapat bekerja ekstra keras dalam menyelesaikan pekerjaannya. Tugas guru tidak hanya mengajar saja tetapi juga dituntut memberikan pelayanan ekstra yang maksimal kepada siswa (pembimbingan dan pendampingan lomba, kegiatan kesiswaan (ektrakurikuler) dan lain-lain), memberi pelayanan kepada sesama guru dan orang tua siswa. Selain itu banyaknya tugas tambahan seperti kegiatan-kegiatan temu ilmiah (seminar, workshop, training, sosialisasi, sarasehan dan lain-lain) dan juga kegiatan-kegiatan kepanitiaan rutin yang banyak bersifat operasional (panitia milad sekolah, wisuda, promosi, program pengenalan sekolah, akreditasi sekolah, panitia seminar/workshop), serta guru harus menghadapi masalah kenakalan siswa dan sebagainya, hal ini membuat guru harus melakukan tugas tersebut diluar jam kerja serta pekerjaan seorang guru yang kompleks membuat kurangnya keseimbangan kehidupan kerja, keadaaan ini termasuk dalam organizational citizenship behavior.
OCB merupakan salah satu faktor yang mempengaruhi subjective well-being. Hasil penelitian Davilia dan Finkelstein (2013) menunjukkan bahwa terdapat hubungan yang positif antara organizatinal citizenship behavior terhadap subjective well-being. Organizational citizenship behavior (OCB) adalah perilaku pilihan yang tidak menjadi bagian dari kewajiban kerja formal seorang karyawan, namun mendukung berfungsinya organisasi tersebut secara efektif (Robbins \& Jugge, 2008). Menurut Organ, Padsakoff \& MacKenzie (2006) OCB merupakan sikap/perilaku karyawan yang dilakukan dengan sukarela, tulus, senang hati tanpa harus diperintah dan dikendalikan oleh organisasi dalam memberikan pelayanan dengan baik. Rioux dan Penner (2001) menambahkan OCB sebagai perilaku proaktif (melakukan pekerjaan di luar deskripsi kerja) atau dengan secara sadar mengajak karyawan lain untuk memenuhi suatu kebutuhan atau kepuasan tertentu atau lebih untuk memotivasi pekerjaan. Selain itu organizational citizenship behavior sangat penting bagi sebuah organisasi karena dapat membantu organisasi berjalan secara efisien dan lebih kompetitif serta mampu meningkatkan kinerja organisasi (Sandjaja \& Handoyo, 2012).

Dengan jumlah guru yang sangat terbatas dan siswa dengan 
jumlah yang banyak dan bervariasinya pekerjaan guru tersebut, guru dituntut untuk memberikan pelayanan dan penyelesaian beban tugas yang maksimal dan tepat waktu. Dibutuhkan pemikiran, keahlian, ketekunan bahkan kreativitas guru dalam menyelesaikannya. Guru harus mampu menunjukkan perilaku ekstra peran, sukarela, tulus, dan senang hati dalam kondisi beban tugas organisasi yang bervariasi tersebut dalam bentuk perilaku OCB nantinya dapat mempengaruhi subjective wellbeing guru. Penelitian ini bertujuan untuk mengetahui hubungan antara organizational citizenship behavior dengan subjective well-being pada guru SMK di Yogyakarta.

\section{METODE PENELITIAN}

Populasi dan sampel

Populasi dalam penelitian ini adalah seluruh Guru perempuan di Sekolah Menengah Kejuruan (SMK) di Yogyakarta. Adapun sampel dalam penelitian ini adalah 150 guru SMK di Yogyakarta. Teknik pengambilan sampel dengan menggunakan simple random sampling.

\section{Metode Pengumpulan Data}

Penelitian ini menggunakan metode skala yang terdiri dari skala subjective well-being dan skala organizational citizenship behavior. Skala subjective well-being disusun berdasarkan konsep Diener, Oishi dan Lucas (2005) bahwa terdapat dua komponen dasar subjective well being yaitu kepuasan hidup (life satisfaction) sebagai komponen kognitif dan kebahagiaan (happiness) sebagai komponen afektif. Skala organizational citizenship behavior mengacu pada aspek-aspek OCB dari Organ, Padsakoff \& MacKenzie (2006) yaitu conscientiousness, altruism, civic virtue, sportmanship, dan courtesy.

\section{Validitas dan Reliabilitas}

Berdasarkan analisis uji coba dan seleksi aitem skala subjective well-being maka didapatkan 22 aitem valid dan 9 aitem gugur dengan korelasi aitem total (rit) terendah 0,305 dan korelasi aitem total tertinggi sebesar 0,627. Hasil analisis koefisien alpha diperoleh indeks reliabilitas alat ukur sebesar 0,879 yang berarti bahwa alat ukur tersebut reliabel dan dapat digunakan sebagai alat ukur yang memadai dalam pengumpulan data penelitian.

Berdasarkan analisis uji coba dan seleksi aitem skala organizational citizenship behavior maka didapatkan 15 aitem valid dan 5 aitem gugur dengan korelasi aitem total (rit) terendah 0,341 dan korelasi aitem total tertinggi sebesar 0,748 . Hasil analisis koefisien alpha diperoleh indeks reliabilitas alat ukur sebesar 0,902 yang berarti bahwa alat ukur tersebut reliabel dan dapat digunakan sebagai alat ukur yang memadai dalam pengumpulan data penelitian. 
Model Analisis Data

Analisis data yang digunakan dalam penelitian ini adalah teknik korelasi product moment dari Pearson. Sebelum melakukan analisis data menggunakan teknik korelasi product moment, terlebih dahulu dilakukan uji asumsi yang meliputi uji normalitas dan uji linearitas. Analisis data dilakukan dengan menggunakan Statisik SPSS for Windows Release 17.0.

\section{HASIL DAN PEMBAHASAN}

Uji Asumsi

Uji Normalitas

Berdasarkan hasil uji normalitas menunjukkan bahwa subjective well-being dengan $\mathrm{p}=0,355(\mathrm{p}>0,05)$ memiliki sebaran normal dan organizational citizenship behavior dengan $\mathrm{p}=0,380$ $(\mathrm{p}>0,05)$ memiliki sebaran yang normal.

\section{Uji Linieritas}

Berdasarkan uji linearitas subjective well-being dan organizational citizenship behavior menunjukkan nilai taraf signifikansi $\mathrm{p}$ (F-linearity) sebesar 0,000 $(\mathrm{p}<0,05)$ dan taraf signifikansi $\mathrm{p}$ (deviation from linearity) sebesar $0,730 \quad(p>0,05) \quad$ yang berarti korelasinya linier.

\section{Hasil Uji Hipotesis}

Berdasarkan hasil uji hipotesis antara subjective well-being dan organizational citizenship behavior diperoleh hasil koefisien korelasi sebesar 0,346 dengan signifikansi $0,000(p<0,01)$, sehingga dapat diinterpretasikan bahwa terdapat hubungan yang sangat siginfikan antara subjective wellbeing dan organizational citizenship behavior.

Hasil penelitian menunjukkan adanya pengaruh antara organizational citizenship behavior dengan subjective well-being. Hal tersebut sesuai dengan penelitian sebelumnya yang dilakukan oleh Yurcu, Colakoglu dan Atay (2015), penelitian ini menunjukkan hasil bahwa organizational citizenship behavior berhubungan positif dengan subjective well-being. Dimensi organizational citizenship behavior berpengaruh positif terhadap subjective well-being. Altruisme mempengaruhi subjective well-being positif dan civic virtue mempengaruhi subjective well-being secara positif. Selanjutnya penelitian yang dilakukan oleh Liqwiyanti dan Jangkung (2016) berdasarkan penelitian tersebut didapatkan hasil terdapat hubungan positif sangat signifikan antara subjective wellbeing dan organizational citizenship behavior pada karyawan hotel.

Penelitian selanjutnya yang dilakukan oleh Spik (2016) berdasarkan penelitian tersebut didapatkan hasil bahwa organizational citizenship behavior mempunyai korelasi positif dengan life satisfaction. Life satisfaction yang termasuk dalam komponen subjective well-being memberikan dampat yang berpengaruh terhadap 
organizational citizenship behavior. Penelitian lain yang dilakukan oleh Filsafati dan Ratnaningsih (2016) hasil dari penelitian tersebut didapatkan bahwa terdapat hubungan positif dan signifikan antara kedua variabel. Hal ini sejalan dengan hasil yang di dapatkan bahwa organizational citizenship behavior berpengaruh signifikan terhadap subjective well-being.

OCB berperan penting bagi upaya meningkatkan kinerja organisasi adalah mengurangi kebutuhan akan sumber daya-sumber daya yang langka/ mahal untuk fungsi-fungsi perawatan/ perbaikan dalam organisasi (Organ,1988), memberi keleluasaan bagi karyawan untuk lebih produktif (Borman \& Motowidlo,1993), meningkatkan produktifitas hubungan kerja atau manajerial (Organ, 1988), serta meningkatkan kemampuan organisasi untuk menarik minat dan mempertahankan karyawan terbaiknya untuk bekerja di situ dengan menciptakan suasana kerja yang menyenangkan (Organ,1988)

Guru yang menunjukkan perilaku OCB yang rendah menunjukkan rendahnya perilaku conscientiousness (rendahnya perilaku datang ke kantor lebih awal dan kehadiran yang cukup tinggi), rendahnya perilaku altruism (tidak membantu dosen lain yang pekerjaannya overload dan menolak mengerjakan tugas dosen lain pada saat tidak masuk), randahnya perilaku civic virtue (tidak terlibat dan bekerjasama dengan tim dan memberikan perhatian terhadap pertemuan-pertemuan penting), rendahnya perilaku sportmanship (mengeluh dan protes terhadap keadaan yang kurang ideal, membesar-besarkan masalah kecil/ sepele, dan meremehkan keadaan), dan rendahnya perilaku courtesy (hormat kepada sesama dan membuat langkah-langkah untuk meredakan/ mengurangi berkembangnya suatu masalah).

Hasil penelitian Crospazano, Byrne, \& Rupp (2003) membuktikan bahwa bila OCB dapat terjadi pada satu organisasi, maka kelelahan kerja (exhaustion) karyawan, intensitas pindah kerja, dan rendahnya kualitas kerja akan dapat ditekan. Pendapat tersebut didukung oleh Hui, Lawa \& Lam (2000) yang mengatakan bahwa dengan adanya perilaku OCB maka karyawan akan dapat saling membantu atau mendukung promosi kerja yang lebih baik. Keberadaan karyawan dengan perilaku OCB pada organisasi akan mengantarkan perusahaan pada suatu kondisi yang menguntungkan, karena karyawan akan bekerja lebih efektif dan akan ikut bekerja maksimal mempertahankan organisasi jika organisasi dalam kondisi yang kurang baik. Penelitian telah menunjukkan bahwa dorongan OCB memiliki dampak positif yang kuat pada hasil kerja individual yang bervariasi (Podsakoff, MacKenzie, Paine, \& Bachrach, 2000). Dengan adanya OCB maka maka subjective well-being dapat terwujud dalam diri guru. 


\section{KESIMPULAN}

Kesimpulan hasil penelitian ini bahwa terdapat hubungan yang sangat siginfikan antara subjective well-being dan organizational citizenship behavior.

\section{DAFTAR PUSTAKA}

Astuti, Y., \& Anganthi, N. R. N. (2016). Subjective well-being pada remaja dari keluarga broken home. Jurnal Penelitian Humaniora, 17, 161 175.

Borman, W. C., \& Motowidlo, S. J. (1993). Expanding the criterion domain to include elements of extra-role performance. In Schmitt, N \& Borman, W. C. (ed), Personnel Selection in Organizations. San Francisco: Jossey-Bass.

Crospazano, R., Byrne, Z.S., \& Rupp, A.E. (2003). The relationship of emotional exhaustion to work attitudes, job performance, and organizational citizenship behavior. Journal of Apllied Psychology. 88, (1), 160-169.

Davilia, M. C., \& Finkelstein, M. A. (2013). Organizational citizenship behaviour and wellbeing: Preliminary results. International Journal of Applied Psychology, 3(3), 4551.
Diener, E., Oshi, S., \& Lucas, R. (2005). Subjective Well-Being: The science od happiness and life satisfaction. Handbook of positif psychology. Oxford: Oxford University Press.

Fahrunnisak \& Qudsyi, H. (2015). Perbedaan subjective wellbeing antara guru bersertifikasi dan non sertifikasi. Jurnal RAP UNP, 6(2), 126-135.

Hui, C., Lawa, K. K. S., \& Lam, S. S. K. (2000). Instrumental values of organizational citizenship behavior for promotin: A field quasiexperiment. Journal of Apllied Psychology. 85(5), 822-828.

Liqwiyanti, A, E., \& Jangkung, D, Y. (2016). Hubungan subjective well-being dan organizational citizenship behavior pada karyawan hotel Aryaduta Jakarta. Jurnal Ilmiah Psikologi. 9, 152-160

Lopez, S. J. dan Synder, C. R. (2007). Positive psychology. Thousand Oaks: Sage Publications

Nayana, F. N. (2013). Keberfungsian keluarga dan subjective wellbeing pada remaja. Jurnal Ilmiah Psikologi Terapan, 1(2), 230-244.

Organ, D.W., Padsakoff, P.M., \& MacKenzie, S.B. (2006). Organizational citizenship behaviour: Its nature, 


\author{
antecendents, and \\ consequences. USA: Sage \\ Publication.
}

Pavot, W. \& Diener, E. (2004). The Subjective evaluation of wellbeing in adulthood: Findings and Implication. Ageing International, 2 (2), 113-135.

Podsakoff, P. M., MacKenzie, S. B., Paine, J. B., \& Bachrach, D. G. (2000). Organizational citizenship behaviors: A critical review of the theoretical and empirical literature and suggestions for future research. Journal of Management, 26(3), 513-563.

Rioux S. M., \& Penner, L. A. (2001). The cause of organizatonal citizenship behavior: A motivational analysis. Journal Apllied Psychology, 86(6), 1306-1314.

Robbins, S. P. \& Judge, T. A. (2008). Perilaku organisasi. Jakarta: Salemba Empat.

Sandjaja, M., \& Handoyo, S. (2012). Pengaruh leader member exchange dan work family conflict terhadap organizational citizenship behavior. Jurnal Psikologi Industri dan Organisasi, 1(2), 55-62.

Sanjaya, W. (2006). Strategi pembelajaran: Berorientasi standar proses pendidikan. Jakarta: Kecana

Yurcu, G., Colakoglu, U., \& Atay, H. (2015). The effect of organizational citizenship behavior on subjective wellbeing. International Journal of Business and Social Science, 6(8), 120-130. 